\title{
STRATEGI PENGELOLAAN RISIKO RANTAI PASOK KOMODITAS KENTANG DI KABUPATEN BANDUNG
}

\author{
Inggit Riszia Pernanda, Akhmad Riyadi Wastra* dan Akhmad Mahbubi Mufti
}

\begin{abstract}
ABSTRAK
Penelitian ini bertujuan untuk: (1) Mengetahui flowchart rantai pasokan kentang di Kabupaten Bandung, (2) Mengidentifikasi risiko yang timbul dari rantai pasokan kentang di Kabupaten Bandung, (3) Mengukur risiko pada setiap tingkatan rantai pasokan, (4) Memetakan risiko, dan (5) Mengetahui cara petani, pengumpul dan distributor memanajemen risiko di Kabupaten Bandung. Penelitian ini menggunakan metode tulang ikan, aproksimasi, dan Matrix Chart. Manajemen risiko dilakukan dengan menghindari, mengontrol, mentransfer, dan menerima risiko. Hasil penelitian ini menunjukkan terdapat risiko 20 per kegiatan di tingkat petani, 7 per kegiatan di tingkat kolektor dan 10 per kegiatan di tingkat distributor. Berdasarkan pengukuran metode pendekatan yang menunjukkan nilai risiko tertinggi terdapat di tingkat tingkat petani, kemudian distributor, dan terendah di tingkat kolektor. Berdasarkan pemetaan, petani dan distributor terletak pada kuadran I, sementara kolektor terletak di kuadran IV. Berdasarkan prioritas manajemen, dilakukan dengan menghindari, mengurangi, mentransfer, menerima risiko, menunjukkan ada 26 tindakan mitigasi yang dapat direalisasikan untuk mengurangi penyebab risiko tersebut.
\end{abstract}

Kata kunci: risiko, kentang, rantai pasokan, manajemen risiko

\begin{abstract}
This study aims to: (1) Know flowchart potato supply chain in Bandung regency. (2) Identify the risks arising from potato supply chain in Bandung regency. (3) Measure the risk at each level of the supply chain. (4) Map the risk. (5) know the way of farmers risk management, collectors and distributors in Bandung regency. This study uses a fish bone, Approximations, and Matrix Chart. The management of risk will determine by avoiding, controlling, transferring, and accepting the risk. The results of this study show risks of 20 per event at the farm level, 7 per event risk at the level of the collector and 10 per event at the distributor level. Based on the measurements of approximation methods are show the highest value at the farm level, then the distributor, and the lowest for the collector. Based on the mapping of the level of farmers and distributors located in quadrant I, while the level of collection is located in quadrant IV. Based on management priorities, held by avoiding, mitigating, transferring, keeping risks, shows there are 26 mitigation actions that can be realized to reduce the causes of such risks.
\end{abstract}

Keywords: risk, potato, supply chain, risk management 


\section{PENDAHULUAN}

Pangan merupakan kebutuhan mendasar bagi kelangsungan hidup manusia. Di Indonesia permintaan pangan terus meningkat seiring peningkatan populasi penduduk selama kurun setengah abad dari 95 Juta jiwa di tahun 1960 menjadi 241 Juta jiwa di tahun 2012 (sumber: BPS RI, 2014). Fenomena tersebut menempatkan ketahanan pangan sebagai isu utama yang menjadi perhatian Indonesia, Ketahanan pangan di Indonesia diatur dalam UU Nomor 18 Tahun 2012 antara lain melalui diversifikasi pangan, swasembada pangan, peningkatan nilai tambah, daya saing dan ekspor, stabilitasi harga dan kesejahteraan petani. Sedangkan diversifikasi pangan diatur dalam Peraturan Presiden (Perpres) No. 22 Tahun 2009 antara lain, memasyarakatka pola konsumsi pangan yang beragam, bergizi, seimbang dan aman serta mengurangi konsumsi beras/kapita 1,5\% per tahun.

Tren konsumsi kentang segar di Indonesia dalam kurun empat tahun terakhir mengalami kenaikan sebesar 30\% (Kementerian Pertanian, 2014). Pada tahun 2009 konsumsi kentang sebesar 1,46 $\mathrm{kg} / \mathrm{kapita} /$ tahun menjadi $1,82 \mathrm{~kg} / \mathrm{kapita} / \mathrm{tahun}$ pada tahun 2012, namun konsumsi kentang yang cenderung meningkat berbanding terbalik dengan produksi kentang nasional. Pada tahun 2009 produksi kentang sebesar 1.176.304 ton dan pada tahun 2012 produksi kentang mencapai 1.094.240 ton, mengalami penurunan sebesar $28 \%$. Provinsi Jawa Barat sebagai daerah penghasil kentang nasional, pada tahun 2009 menghasilkan produksi kentang sebesar 320.542 ton, pada tahun 2012 produksi kentang mencapai 261.966 ton, atau mengalami penurunan sebesar $17 \%$. Kabupaten penghasil kentang di Jawa Barat adalah Kabupaten Bandung, yang menghasikan produksi 128.984 ton pada tahun 2008. Pada tahun 2012 produksi kentang sebesar 131.876 ton, atau mengalami kenaikan sebesar $29 \%$.

\section{METODE PENELITIAN}

\section{Waktu dan Tempat Penelitian}

Penelitian dilaksanakan selama lima bulan, yaitu dari bulan Agustus 2014Desember 2014, bertempat di Kabupaten Bandung. Kabupaten Bandung merupakan salah satu daerah penghasil atau sentra kentang di Provinsi Jawa Barat.

\section{Jenis dan Sumber Data}

Data yang digunakan dalam penelitian ini adalah data primer dan data sekunder.

\section{Teknik Penentuan Sempel}

Sampel yang dijadikan responden atau informan penelitian ditentukan secara Multi Stage Area Sampling. Penentuan jumlah sampel dengan populasi tidak terhingga menurut J. Sarwono (2002: 42) adalah sebagai berikut:

$$
N_{0}=\frac{Z^{2} a / 2 x p(1-p)}{e^{2}}
$$

Dimana :

$$
\begin{aligned}
& \mathrm{Z}=\text { tingkat kepercayaan dugaan }(1-\alpha) \\
& P=\text { proporsi sampel } \\
& \mathrm{e}=\text { kesalahan dugaan (sampling eror) } \\
& \mathrm{n}_{\mathrm{O}}=\text { jumlah sampel awal } \\
& \text { Pada penelitian ini, jumlah sampel } \\
& \text { yang digunakan berjumlah } 120 \\
& \text { responden dengan berdasarkan } \\
& \text { ketentuan-ketentuan berikut ini : } \\
& \text { 1. } \mathrm{Z}=90 \% \text { (tingkat kepercayaan } 90 \% \text { ) } \\
& \text { 2. } P=50 \% \text { (proporsi sampel } 50 \% \text { ) }
\end{aligned}
$$




\section{1. $e=7,5 \%$ (sampling error $7,5 \%$ )}

\section{Teknik Pengumpulan dan Analisis Data}

Pengumpulan data dilakukan dengan kuantitatif, kualitatif, dan melakukan lembar penilaian (assessment sheet) kepada responden untuk dinilai probabilitas $(\mathrm{P})$ dan dampak (D) risiko. Ada 4 teknik menganalisis data yakni: Tahap pertama, identifikasi risiko dengan menggunakan metode fish bone. Tahap kedua, Pengukuran dan Perkiraan Risiko, Metode Pengukuran Risiko (Metode Aproksimasi) dapat dilakukan secara kuantitatif atau kualitatif. Tahap ketiga adalah pemetaan, pemetaan merupakan kelanjutan dari tahap pengukukuran risiko berdasarkan kelompokkelompok tertentu sehingga dapat mengidentifikasi karakter dari setiap risiko dan menetapkan tindakan masing-masing risiko (Hanafi, 2009: 31), pengukuran kuntitatif ini dapat digunakan menggunakan risk matriks chart.

Gambar 1. Diagram Pemetaan Risiko (Risk Matriks Chart)

\begin{tabular}{cc|c|c|c|}
\cline { 3 - 4 } Dampak & 5 & $\begin{array}{c}\text { Kuadran } \\
\text { II }\end{array}$ & Kuadran I \\
\cline { 3 - 5 } & 3 & $\begin{array}{c}\text { Kuadran } \\
\text { IV }\end{array}$ & Kuadran III \\
\cline { 3 - 5 } & 1 & & 5
\end{tabular}

Sumber: Kountur, 2008: 45

Tahap keempat, strategi pengelolaan risiko, berdasarkan strategi yang dilakukan dalam mencegah suatu risiko, tiap rantai pasok dapat melakukan strategi pengurangan risiko, atau seberapa besar risiko yang dapat ditoleransi atau diterima.

\section{Uji Validitas dan Uji Reliabelitas}

Di dalam penentuan layak atau tidaknya suatu item yang akan digunakan, biasanya dilakukan uji signifikan koefisien korelasi pada batasan minimal korelasi 0,30 , artinya suatu item dianggap valid jika skor total lebih besar dari 0.30 (Priyanto, 2010: 62). Uji reliabelitas dalam penelitian ini menggunakan angka cronbach yaitu suatu pertanyaan dalam kuesioner akan reliabel jika cronbach alpha > 0,6 (Ghozali, 2005: 47).

\section{PEMBAHASAN DAN HASIL}

\section{Alur Rantai Pasok Komoditas Kentang Kabupaten Bandung}

1 Petani menjual hasil produksi kentang ke pedagang pengumpul.

2 Petani dapat menjual kentang langsung menuju distributor.

3 Petani sebagai penyedia bahan baku menjual kentang ke pengumpul.

4 Petani sebagai penyedia bahan baku makanan langsung menjual kentang ke industri makanan.

5 Petani sebagai penyedia bahan baku menjual kentang ke pengumpul, di tingkat pengumpul kentang disortir berdasarkan kualitas dan kuantitas sehingga mendapatkan nilai tambah.

6 Petani sebagai penyedia bahan baku menjual kentang langsung ke pengecer di daerah setempat.

\section{Identifikasi Risiko Rantai Pasok}

Resiko Tingkat Petani

Berdasarkan penelitian di lapangan risiko yang sering muncul di tingkat petani yaitu, risiko konversi lahan yang setiap tahun mengangalami pengurangan jumlah lahan produktif, risiko sarana dan prasarana yang tidak memadai, risiko produktivitas yang selalu menurun akibat kurangnya pengetahuan petani maupun dari alam, dan adanya risiko panen dan pasca panen yang kurang tepat karena masih 
banyaknya menggunakan cara yang konvensional.

Resiko Tingkat Pengumpul

Risiko penyortiran yang kurang baik karena masih menggunakan cara-cara yang konvensional dan risiko penyimpanan yang kurang memadai yang berimplikasi banyaknya kentang yang mudah busuk dan berjamur.

Resiko Tingkat Distributor

Berdasarkan penelitian di lapangan, risiko yang dialami tingkat pengumpul, yaitu risiko pengemasan yang masih buruk, dan risiko pengangkutan yang belum sesuai, sehingga banyak kentang yang rusak dan mengalami penyusutan dalam perjalanan menuju ke pasar maupun konsumen.

\section{Tingkat Status Resiko Rantai Pasok}

Berdasarkan perhitungan dengan metode aproksimasi, diperoleh nilai status risiko, untuk tingkat petani dengan nilai 11.18, tingkat pengumpul 8.36, dan tingkat distributor dengan nilai 10.95 .

Gambar 2. Status resiko tingkat rantai pasok.

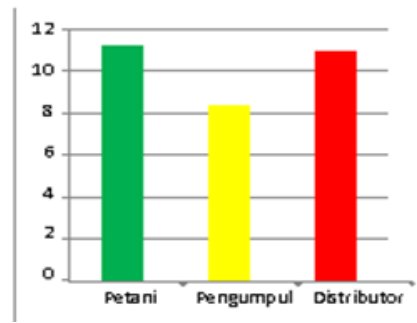

\section{Pemetaan Risiko}

Pemetaan Risiko

Nilai status rata-rata risiko secara keseluruhan jika dipetakan berdasarkan di setiap tingkat rantai pasok yaitu: tingkat petani dan tingkat distributor terletak di kuadaran I, hal ini berarti bahwa tingkat probabilitas sangat tinggi dengan dampak yang ditimbulkan besar yang akan berakibat meruginya petani dan distributor dalam usaha kentang; tingkat pengumpul yang berada dikuadran IV, berarti memiliki tingkat probabilitas yang rendah dan dampak yang kecil yang tidak berakibat terhadap kerugian pengumpul.

Gambar 3. Pemetaan Risiko Tingkat Rantai Pasok

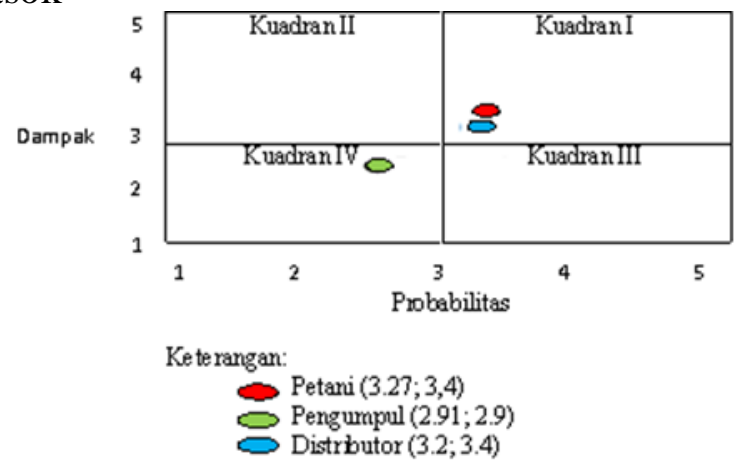

\section{KESIMPULAN}

1 Model rantai pasok komoditas kentang di Kabupaten Bandung menunjukan bahwa pendistribusian kentang menuju konsumen akhir memiliki enam alir rantai pasok, yang bermula dari petani/produsen sebagai sumber penyedia bahan baku

2 Risiko-risiko yang teridentifikasi pada tiap tingkat petani yaitu risiko konversi lahan, sarana dan prasarana, produktivitas, dan penanganan panen dan pasca panen. Tingkat pengumpul teridentifikasi memiliki risiko, yaitu risiko penyortiran, dan penyimpanan. Dan tingkat distributor teridentifikasi memiliki risiko pengemasan dan pengangkutan.

3 Berdasarkan pengukuran risiko, tingkat petani memiliki nilai status risiko yang paling tinggi yaitu sebesar 11.18, disusul tingkat distributor memilki nilai status risiko yaitu sebesar 10.95 dan tingkat pengumpul memiliki nilai status risiko yaitu sebesar 8.36.

4 Berdasarkan pemetaan risiko, tingkat petani dan tingkat distributor terdapat di kuadran I, yang berarti risiko tersebut tergolong sering terjadi dan sangat berbahaya. Tingkat petani memiliki probabilitas sebesar 3.27 dan 
dampak sebesar 3.4, disusul tingkat distributor memilki probabilitas sebesar 3.21 dan dampak sebesar 3.4. Untuk tingkat pengumpul terdapat dikuadran IV, yang berarti risiko tersebut tidak berbahaya, karena memiliki probabilitas sebesar 2.91 dan dampak sebesar 2.9.

5 Berdasarkan pengelolaan risiko, dibuat prioritas pengelolaan berdasarkan pemetaan dan status risiko yang paling besar. Tingkat petani dapat diminimalisasi berdasarkan risiko per kejadian, yaitu terdapat risiko konversi lahan sebesar 13.41, risiko sarana dan prasaran sebesar 11.52, risiko produktivitas sebesar 10.81 dan risiko panen dan pasca panen sebesar 8.97. Tingkat pengumpul dapat diminimalisasi berdasarkan per kejadian, yaitu terdapat risiko penyortiran sebesar 10.78 dan risiko penyimpanan sebesar 6,24. Tingkat distribiutor dapat diminimalisasi berdasarkan per kejadian, yaitu risiko pengangkutan sebesar 11.36 dan terdapat risiko pengemasan sebesar 10.47, selanjutnya dilakukan pengelolaan berdasarkan pemetaan dan nilai status risiko, yaitu dengan pengelolaan menerima risiko (avoid), mengendalikan (mitigate) dan mengalihkan (transfer) yang terjadi pada kuadran I, untuk yang berada di kuadran II menggunakan strategi mengendalikan (mitigate), untuk yang berada di kuadran III dapat menggunakan mengalihkan (transfer) dan untuk yang berada di kuadran IV hanya menerima risiko (keep).

\section{SARAN}

1 Dalam pengelolaan risiko, baik dengan cara menghindari (avoid), mengendalikan (mitigate), mengalihkan (transfer) maupun dengan cara menerima (keep), sangat penting untuk diingat bahwa biaya yang dikeluarkan untuk pengelolaan risiko harus lebih kecil dari dampak yang ditimbulkan.

2 Untuk sumber daya manusia yang menjadi pelaku rantai pasok perlu dilakukan pelatihan untuk mengurangi risiko yang terdapat dalam tiap tingkat rantai pasok.

3 Bagi penelitian selanjutnya, sebaiknya melakukan studi literatur untuk menghitung nilai keuntungan dan nilai kerugian yang diharapkan dari risiko- risiko tiap rantai pasok, sehingga dapat dibandingkan antara keuntungan dan kerugian yang diharapkan dari risiko suatu kegiatan.

\section{DAFTAR PUSTAKA}

Anatan, Lina, dan Ellitan, Lina. Supply Chain Manajemen Teori Dan Aplikasi. Alfabeta. Bandung. 2008.

Arifin, B. Pembangunan Pertanian. PT. GRASINDO. Jakarta. 2005.

Arsyad, S, dan Rustiandi, E. Penyelamatan Tanah, Air, dan Lingkungan. Crestpent Press dan Yayasan Obor Indonesia. 2008.

Badariah, Nurlaila. dkk. Analisa Supply Chain Risk Management Berdasarkan Failure Metode And Effect Analysis (FMEA). Jurnal Teknik Industri, ISSN : 14411-6340. 2010.

Darmawi, Herman. Manajemen Risiko. PT. Bumi Aksara. Jakarta. 2010. 
Fendi, Ari, dan Yuliawati, Evi. Analisis Strategi Mitigasi Risiko Pada Supply Chain PT. PAL. Indonesia (PERSERO). Seminar Nasional Aplikasi Sains dan Teknologi (SNAST) Periode III, ISSN : 1979-911X. November 2012.

Ghozali, Imam. Aplikasi Multivariate Dengan Program SPSS. Universitas Diponegoro, Semarang, 2006.

Hanafi, MM. Manajemen Risiko. UPP STIM YKPN. Yogyakarta, 2006. Hanafie, R. Pengantar Ekonomi Pertanian. CV Andi Offset. Yogyakarta, 2010.

Hanggraeni, Dewi. Pengelolaan Risiko Usaha. Lembaga Penerbit Fakultas Ekonomi UI. Jakarta. 2008.

Kountur, R. Mudah Memahami Manajemen Risiko Perusahaan. PPM. Jakarta,2008. Kuswanto, Hedarto. Teknologi Pemrosesan, Pengemasan, dan Penyimpanan Benih.

Kanisius. Jakarta. 2007.

Marimin, dan Maghfiroh, Nurul. Aplikasi Teknik Pengambilan Keputusan Dalam Manajemen Rantai Pasok. IPB Press, Bogor. 2010.

Mulyadi. Sistem Perencanaan dan Pengendalian Manajemen. Salemba Empat. Yogyakarta. 2007
Parenrengi, Syarifudin M. dkk. Analisis Risiko Supply Chain Management Dalam Membangun Ketangguhan Perusahaan Dengan Metode Failure and Effects Analysis (FMEA). Hasil Penelitian Fakultas Teknik Vol 5. Desember 2011

Priyanto, Dwi. Mari Belajar SPP. Mediakom. Yogyakarta, 2008.

Pujawan, I., N. Suplly Chain Management. Institut Teknologi Sepuluh Nopember. Surabaya. 2005.

Samadi, B. Usaha Tani Kentang. Penerbit Kanisius. Yogyakarta. 2005. Samadi, B. Kentang dan Analisis Usaha Tani. Yogyakarta. 2007. Sarwono, J. Mixed Methods. PT Gramedia. Jakarta. 2002.

Setiadi. Budi Daya Kentang. Penebar Swadaya. Bogor. 2009. Sofyan, I. Manajemen Risiko. Graha Ilmu. Yogyakarta. 2004.

Suharjito. Dkk. Identifikasi dan Evaluasi Risiko Manajemen Rantai Pasok Komoditas jagung dengan Pendekatan Logika Fuzzy. Jurnal Manajemen dan Organisasi. Vol 1. No. 2. 2010.

Suharjito. Dkk. Pemodelan Optimasi Mitigasi Risiko Rantai Pasok/Komoditas Jagung. Jurnal Agritech. Vol. 31. 2011

Sukoco, Y. Pertanian Masa Depan. Kanisius. Yogyakarta. 2008. 
Sunarjono, Hendro. Petunjuk Praktis Budi Daya Kentang. PT Agromedia Pustaka. Tangerang. 2007

Suswono, dan Suryana, Acmad. Roadmap Diversifikasi Pangan Tahun 2011 - 2015. Kementerian Pertanian. Jakarta. 2012.

Trangjiwani, Wungkir. Manajemen Risiko Operasional CV Bimandiri di Lembang, Kabupaten Bandung Propinsi Jawa Barat. Hasil Penelitian Fakultas Pertanian IPB. Bogor. 2008

Wastra, Riyadi Akhmad dan Mahbubi, Akhmad. Risiko agribisnis. UIN Jakarta Press. Jakarta. 2013.

www.perpuskita.com/budidayakentang/307/. Diakses pada tanggal 5 April 2014.

* Alamat Korespondensi: riyadi.wastra@uinjkt.ac.id 